\title{
SISTEM PENYELEKSI MAHASISWA BARU BERBASIS WEB MENGGUNAKAN METODE WEIGHTED PRODUCT
}

\author{
Arifin Tua Purba ${ }^{1)}$, Victor Marudut Mulia Siregar ${ }^{2)}$ \\ Teknik Komputer, Politeknik Bisnis Indonesia \\ email: ${ }^{1}$ arifintuaprb20@gmail.com, ${ }^{2}$ victor.siregar2@gmail.com
}

\begin{abstract}
This research was conducted aiming to design a New Student Selection Decision Support System. To help the selection process for new student admissions at the Indonesian Business Polytechnic, a decision support system (SPK) was designed to help the data processing of prospective new students who register using the Weighteded Product (WP) method. This Weighteded Product method is done by using multiplication to link the attribute rating, where the rating of each attribute must be raised first with the Weighted of the attribute in question. The criteria used in this Decision Support System consist of: capacity, achievement, academic tests, age, and passing scores. From the sample of data examined, the ranking results were found to be the best value of prospective students with a value of 0.0841 and 0.0791 .
\end{abstract}

Keywords : Decision Support System, Selection, Criteria, Weighteded Product

\section{PENDAHULUAN}

Kebutuhan akan informasi yang dijadikan sebagai dasar pengambilan keputusan di dalam setiap organisasi semakin dibutuhkan. Oleh karena itu semakin banyak pengambilan keputusan saat ini melibatkan penggunaan teknologi komputer [1]-[5], [6]. Pemanfaatan teknologi pada perkembangannya sangat berperan dalam kehidupan [7]-[11], [12], [13], [14]-[18].

Politeknik Bisnis Indonesia berdiri yang berdiri sejak tahun 2011, terus mengalami pertumbuhan secara signifikan yakni semakin tingginya animo masyarakat terhadap institusi pendidikan vokasi sehingga kuantitas mahasiswa baru pun terus meningkat. Dengan menerima mahasiswa yang berkompeten maka dapat menunjang mutu dan kualitas perguruan tinggi itu sendiri. Hal ini menunjukkan pentingnya pengelolaan proses penerimaan mahasiswa baru demi tercapainya peningkatan mutu perguruan tinggi.

Saat ini, sistem penerimaan mahasiswa di Politeknik Bisnis Indonesia masih menggunakan ujian tertulis dan belum menggunakan teknik pengambilan keputusan tertentu. Oleh karena itu, perlu dirancang sebuah sistem penunjang keputusan penerimaan mahasiswa dengan melibatkan berbagai kriteria, sehingga dapat diseleksi calon-calon mahasiswa yang baik dan berkompeten sesuai dengan visi dan misi
Politeknik Bisnis Indonesia dan siap dengan persaingan global sesuai dengan bidang keilmuan masing-masing.

Sistem pengambilan keputusan yang baik dan terstruktur akan menghasilkan sistem yang dapat menunjang kredibilitas Politeknik Bisnis Indonesia dalam menghasilkan mahasiswamahasiswa terbaik. Sistem Pengambilan keputusan penerimaan mahasiwa baru ini menggunakan metode Weighted Product, metode ini digunakan karena dapat memberikan solusi yang baik dalam pemilihan keputusan [19]-[24].

\section{METODE PENELITIAN}

Sistem penyeleksian mahasiswa baru ini dibangun dengan tahapan perancangan sistem yang dimulai dari membuat model arsitektur SPK, Context Diagram, Data Flow Diagram dan Entity Relationship Diagram.

Pada context diagram terdapat dua pengguna yaitu panitia penerimaan mahasiswa baru sebagai admin atau user dan Direktur. Panitia penerimaan mahasiswa baru memberikan inputan pada sistem pendukung keputusan penerimaan mahasiswa baru berupa data calon mahasiswa, nilai dan kriteria. Panitia akan mendapatkan output dari sistem berupa daftar calon mahasiswa. Direktur akan mendapatkan ouput dari sistem berupa informasi hasil laporan seleksi penerimaan mahasiswa baru di Politeknik Bisnis Indonesia. Direktur bisa melihat hasil nilai 
yang diperolehnya dan juga urutan peringkat hasil seleksi metode Weighted Product, seperti pada gambar 1 .

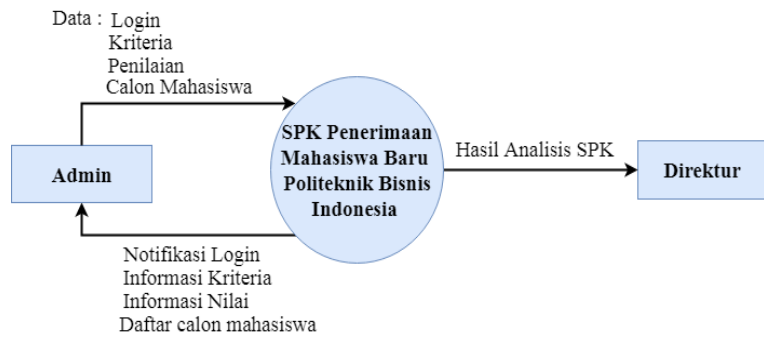

Gambar 1. Context Diagram

\section{Entity relationship diagram}

Entity relationship diagram merupakan diagram perancangan database dimana terdapat entitas sebagai calon tabel dan relasi sebagai hubungan antar entitas tersebut. Entity relationship diagram Sistem Penyeleksian mahasiswa baru menggunakan metode Weighted Product dapat dilihat pada gambar 2.

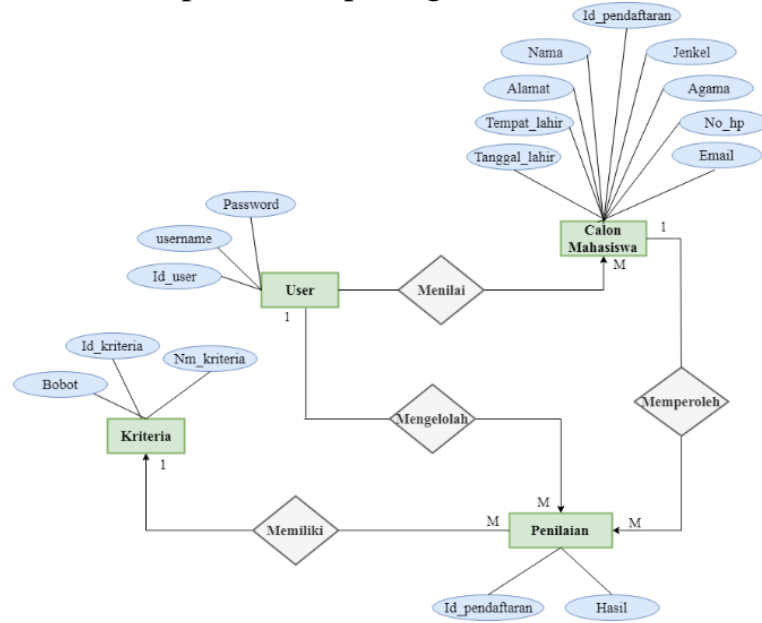

Gambar 2. ERD Sistem

Analisis Kebutuhan Untuk Metode Weighted Product

Perangkingan alternatif pada Sistem Pendukung Keputusan Penerimaan Mahasiswa Baru dengan metode Weighted Product dapat dijelaskan setelah admin memasukkan bobot dari setiap kriteria, selanjutnya adalah menghitung nilai untuk alternatif $\mathrm{W}_{\mathrm{j}}$. Kemudian menentukan perangkingan alternatif, di mana nilai $\mathrm{V}_{\mathrm{i}}$ yang terbesar adalah alternatif yang terpilih dan menjadi alternatif terbaik, dapat dilihat seperti gambar 3.

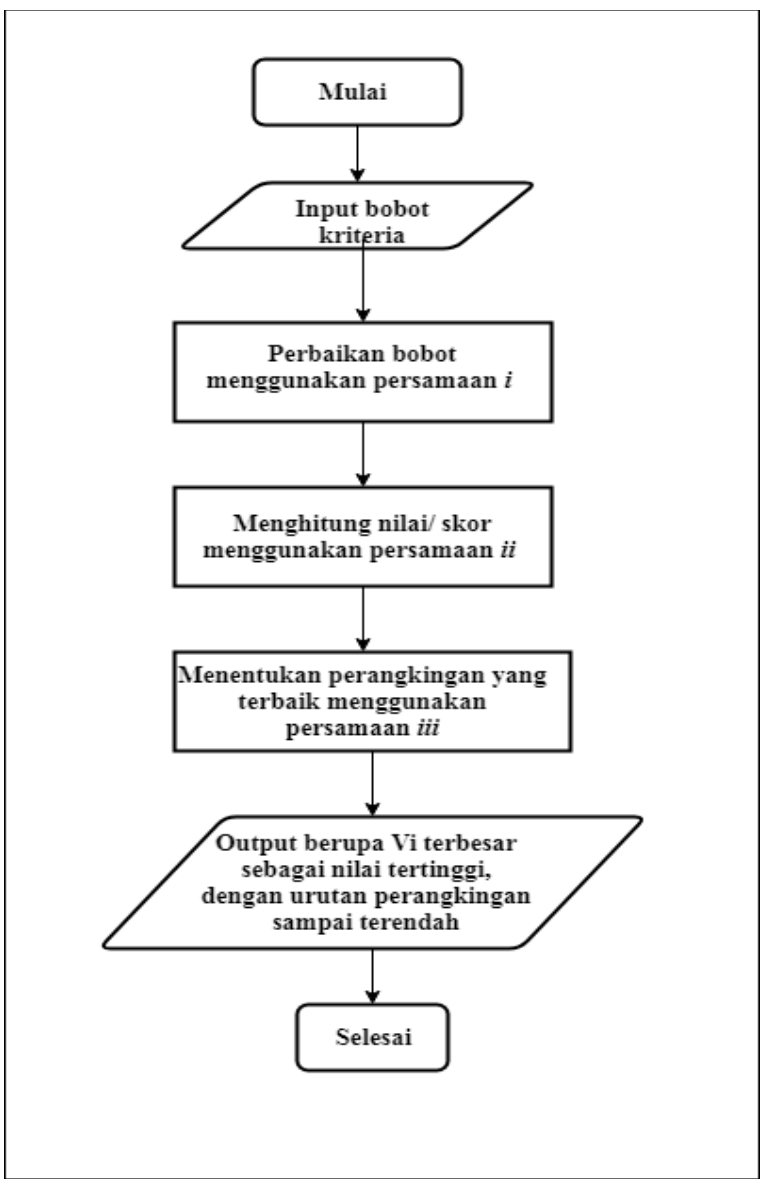

Gambar 3. Flowchart Metode WP

\section{Kriteria Penilaian}

Sistem pendukung keputusan pennyeleksian mahasiswa baru di Politeknik Bisnis Indonesia ini memiliki beberapa data inputan yang akan digunakan sebagai kriteria dan selanjutnya akan diproses menggunakan metode Wieght Product. Kriteria tersebut diantaranya :

1. Daya tampung

2. Prestasi

3. Test Akademik

4. Usia

5. Nilai kelulusan

Perhitungan seleksi penerimaan mahasiswa baru terbagi atas seleksi daya tampung sebagai kriteria $\mathrm{C} 1$, seleksi Prestasi sebagai kriteria $\mathrm{C} 2$, seleksi test akademik sebagai kriteria C3, seleksi usia sebagai criteria $\mathrm{C} 4$, dan selesksi nilai kelulusan sebagai krietria C5.

Selanjutnya diberikan sampel data nilai pada semua kriteria yang ada. Dari seluruh calon mahasiwa yang telah melakukan pendaftaran, 
diambil 15 data mahasiswa sebagai contoh untuk penerapan dari metode Weighted Product (WP). Setelah mengetahui data calon mahasiswa baru, selanjutnya memberi bobot kriteria untuk masing-masing data calon mahasiswa seperti pada Tabel 1.

Tabel 1. Bobot Kriteria

\begin{tabular}{|l|l|l|l|l|l|}
\hline \multirow{2}{*}{\multicolumn{1}{|c|}{ Alternatif }} & \multicolumn{5}{|c|}{ Kriteria } \\
\cline { 2 - 6 } & C1 & C2 & C3 & C4 & C5 \\
\hline $\begin{array}{l}\text { Fikri Yuda } \\
\text { Wiguna }\end{array}$ & 3 & 3 & 3 & 5 & 3 \\
\hline Gabriel A Purba & 3 & 3 & 3 & 4 & 4 \\
\hline Marini Silalahi & 3 & 5 & 3 & 5 & 3 \\
\hline $\begin{array}{l}\text { Friska M M } \\
\text { Gultom }\end{array}$ & 3 & 5 & 5 & 5 & 4 \\
\hline Yusriadi & 3 & 3 & 2 & 5 & 4 \\
\hline Krissafat Gea & 3 & 4 & 3 & 4 & 4 \\
\hline $\begin{array}{l}\text { Dickey } \\
\text { Hardiansyah }\end{array}$ & 3 & 4 & 4 & 5 & 4 \\
\hline Rikijan Sijabat & 3 & 4 & 4 & 3 & 4 \\
\hline $\begin{array}{l}\text { Muhammad } \\
\text { Alpin }\end{array}$ & 3 & 4 & 3 & 4 & 3 \\
\hline Dian Marta & 3 & 4 & 4 & 3 & 4 \\
\hline $\begin{array}{l}\text { I'msee } \\
\text { Hutabarat }\end{array}$ & 3 & 2 & 2 & 5 & 3 \\
\hline Rini Ginting & 3 & 2 & 3 & 5 & 4 \\
\hline Mitra N Saragih & 3 & 3 & 3 & 5 & 4 \\
\hline $\begin{array}{l}\text { Lane E } \\
\text { Matanari }\end{array}$ & 3 & 4 & 3 & 5 & 4 \\
\hline Adam Bastian & 3 & 2 & 3 & 5 & 3 \\
\hline
\end{tabular}

Kemudian mencari nilai S setiap kriteria dari alternatif dipangkatkan dengan bobot yang telah diperbaiki sesuai dengan kriteria masing.

$$
\begin{aligned}
& S_{1}=\left(3^{0,1}\right)\left(3^{0,2}\right)\left(3^{0,3}\right)\left(5^{-0,1}\right)\left(3^{0,3}\right)=2,2883 \\
& S_{2}=\left(3^{0,1}\right)\left(3^{0,2}\right)\left(3^{0,3}\right)\left(4^{-0,1}\right)\left(4^{0,3}\right)=2,5508 \\
& S_{3}=\left(3^{0,1}\right)\left(5^{0,2}\right)\left(3^{0,3}\right)\left(5^{-0,1}\right)\left(3^{0,3}\right)=2,5344 \\
& S_{4}=\left(3^{0,1}\right)\left(5^{0,2}\right)\left(5^{0,3}\right)\left(5^{-0,1}\right)\left(4^{0,3}\right)=3,2205 \\
& S_{5}=\left(3^{0,1}\right)\left(3^{0,2}\right)\left(2^{0,3}\right)\left(5^{-0,1}\right)\left(4^{0,3}\right)=2,2089 \\
& S_{6}=\left(3^{0,1}\right)\left(4^{0,2}\right)\left(3^{0,3}\right)\left(4^{-0,1}\right)\left(4^{0,3}=2,7019\right. \\
& S_{7}=\left(3^{0,1}\right)\left(4^{0,2}\right)\left(4^{0,3}\right)\left(5^{-0,1}\right)\left(4^{0,3}\right)=2,78805 \\
& S_{8}=\left(2^{0,1}\right)\left(4^{0,2}\right)\left(4^{0,3}\right)\left(3^{-0,1}\right)\left(4^{0,3}=3,0314\right. \\
& S_{9}=\left(3^{0,1}\right)\left(4^{0,2}\right)\left(3^{3,3}\right)\left(4^{-0,1}\right)\left(3^{0,3}\right)=2,4785 \\
& S_{10}=\left(3^{0,1}\right)\left(4^{0,2}\right)\left(4^{0,3}\right)\left(3^{-0,1}\right)\left(4^{0,3}\right)=3,0314 \\
& S_{11}=\left(3^{0,1}\right)\left(2^{0,2}\right)\left(2^{0,3}\right)\left(5^{-0,1}\right)\left(3^{0,3}\right)=1,8684 \\
& S_{12}=\left(3^{0,1}\right)\left(2^{0,2}\right)\left(3^{0,3}\right)\left(5^{-0,1}\right)\left(4^{0,3}\right)=2,3003 \\
& S_{13}=\left(3^{0,1}\right)\left(3^{0,2}\right)\left(3^{0,3}\right)\left(5^{-0,1}\right)\left(4^{0,3}\right)=2,4946
\end{aligned}
$$

$\mathrm{S}_{14}=\left(3^{0,1}\right)\left(4^{0,2}\right)\left(3^{0,3}\right)\left(5^{-0,1}\right)\left(4^{0,3}\right)=2,6423$

$\mathrm{S} 1_{5}=\left(3^{0,1}\right)\left(2^{0,2}\right)\left(3^{0,3}\right)\left(5^{-0,1}\right)\left(3^{0,3}\right)=2,1101$

Selanjutnya menghitung nilai prefensi alternatif $(\mathrm{V})$ untuk perankingan setiap alternatif pada tabel 2 .

Tabel 2. Prefensi Alternatif

\begin{tabular}{|l|l|}
\hline $\begin{array}{l}\text { Prefensi } \\
\text { alternatif }\end{array}$ & Nama alternatif \\
\hline $\mathrm{V}_{1}$ & Fikri Yuda Wiguna \\
\hline $\mathrm{V}_{2}$ & Gabriel A Purba \\
\hline $\mathrm{V}_{3}$ & Marini Silalahi \\
\hline $\mathrm{V}_{4}$ & Friska M M Gultom \\
\hline $\mathrm{V}_{5}$ & Yusriadi \\
\hline $\mathrm{V}_{6}$ & Krissafat Gea \\
\hline $\mathrm{V}_{7}$ & Dickey Hardiansyah \\
\hline $\mathrm{V}_{8}$ & Rikijan Sijabat \\
\hline $\mathrm{V}_{9}$ & Muhammad Alpin \\
\hline $\mathrm{V}_{10}$ & Dian Marta \\
\hline $\mathrm{V}_{11}$ & I,msee Hutabarat \\
\hline $\mathrm{V}_{12}$ & Rini Ginting \\
\hline $\mathrm{V}_{13}$ & Mitra N Saragih \\
\hline $\mathrm{V}_{14}$ & Lane E Matanari \\
\hline $\mathrm{V}_{15}$ & Adam Bastian \\
\hline
\end{tabular}

Berdasarkan hasil perhitungan $\mathrm{V}$ diatas diperoleh hasil perankingan maka didapat nilai terbesar yang menjadi alternatif terbaik. Pada Tabel 3 dapat dilihat hasil perangkingan penerimaan Mahasiswa.

Table 3. Hasil Perangkingan

\begin{tabular}{|c|l|c|}
\hline $\begin{array}{c}\text { Perang- } \\
\text { kingan }\end{array}$ & \multicolumn{1}{|c|}{ Alternatif } & Hasil \\
\hline 1 & Friska M M Gultom & 0,0840 \\
\hline 2 & Dian Marta & 0,0791 \\
\hline 3 & Rikijan Sijabat & 0,0791 \\
\hline 4 & Dickey Hardiansyah & 0,0751 \\
\hline 5 & Krissafat Gea & 0,0705 \\
\hline 6 & Lane Ertika Matanari & 0,0689 \\
\hline 7 & Gabriel Andrian Purba & 0,0665 \\
\hline 8 & Marini Silalahi & 0,0661 \\
\hline & Mitra Novriadi & \\
\hline 9 & Saragih & 0,0651 \\
\hline 10 & Muhammad Alpin & 0,0646 \\
\hline 11 & Rini Ginting & 0,0600 \\
\hline 12 & Fikri Yuda Wiguna & 0,0597 \\
\hline 13 & Yusriadi & 0,0576 \\
\hline
\end{tabular}




\begin{tabular}{|l|l|l|}
\hline 14 & Adam Bastian & 0,0550 \\
\hline 15 & I,msee Hutabarat & 0,0487 \\
\hline
\end{tabular}

\section{Perancangan antarmuka}

Perancangan Antarmuka meliputi perancangan struktur menu dan perancangan tampilan pengguna.

\section{Halaman Login}

Berupa proses pintu masuk bagi User/admin untuk mengakses sistem komputer dengan cara memasukkan username dan password seperti pada gambar 4 .

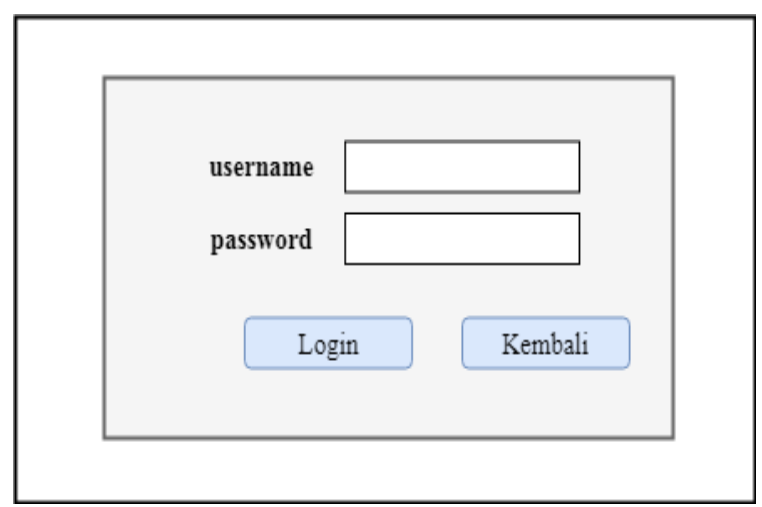

Gambar 4. Halaman Login

\section{Halaman Beranda}

Merupakan menu utama yang akan tampil pada saat pertama kali admin login.

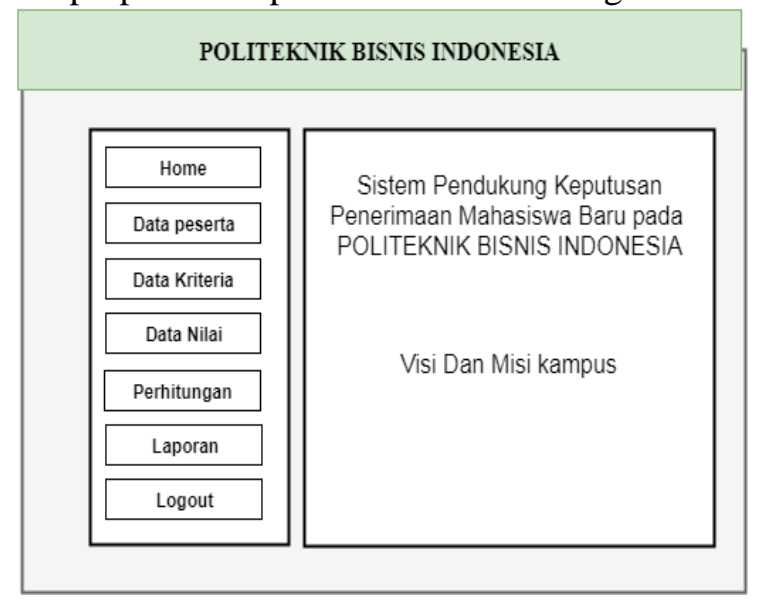

Gambar 5. Halaman Beranda

\section{Halaman Data Calon Mahasiswa Baru}

Halaman ini berfungsi untuk menginput data semua calon mahasiswa baru, yang diinput oleh admin/ user seperti pada gambar 6 .

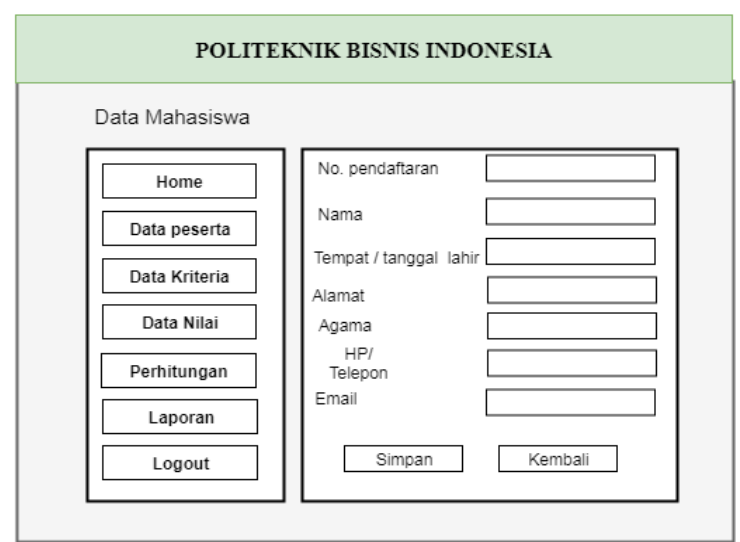

Gambar 6. Halaman Data Calon Mahasiswa

\section{Halaman Daftar Calon Mahasiswa}

Halaman ini berfungsi untuk menampilkan daftar calon mahasiswa yang di input seperti pada gambar 7 .

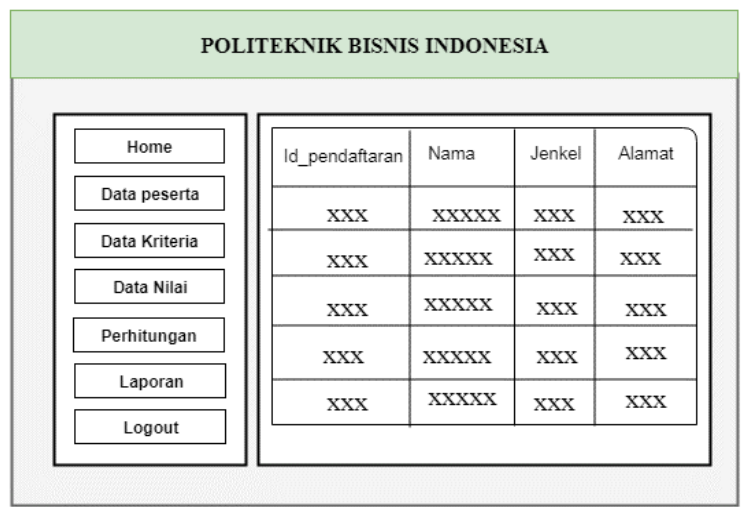

Gambar 7. Halaman Daftar Calon Mahasiswa

\section{Halaman Data Kriteria}

Halaman Data Kriteria berfungsi untuk menginput semua data-data kriteria yang ada pada calon mahasiswa baru. Halaman Data Kriteria ini dapat dilihat pada gambar 8 .

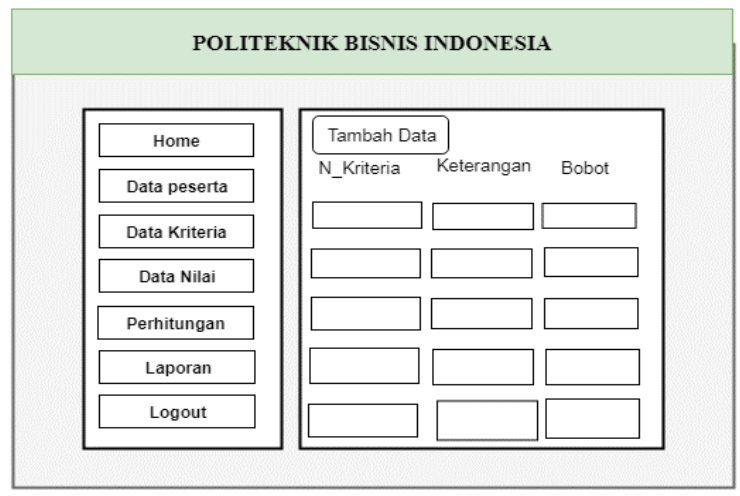

Gambar 8. Halaman Data Kriteria 


\section{Halaman Nilai}

Halaman ini berfungsi untuk mencatat semua penilaian untuk kriteria yang ada pada mahasiswa seperti pada gambar 9 .

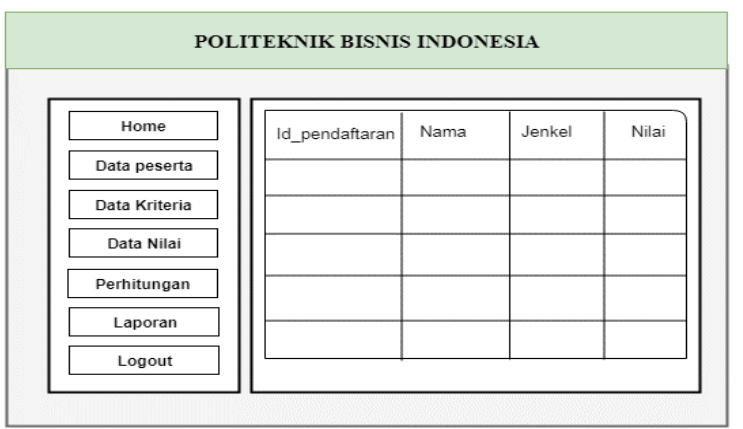

Gambar 9. Halaman Nilai

Halaman Perhitungan

Halaman ini menampilkan hasil perhitungan dari setiap kriteria, mulai dari nilai hasil perhitungan normalisasi bobot, vektor $\mathrm{S}$ dan vektor V. Dapat dilihat seperti gambar 10.

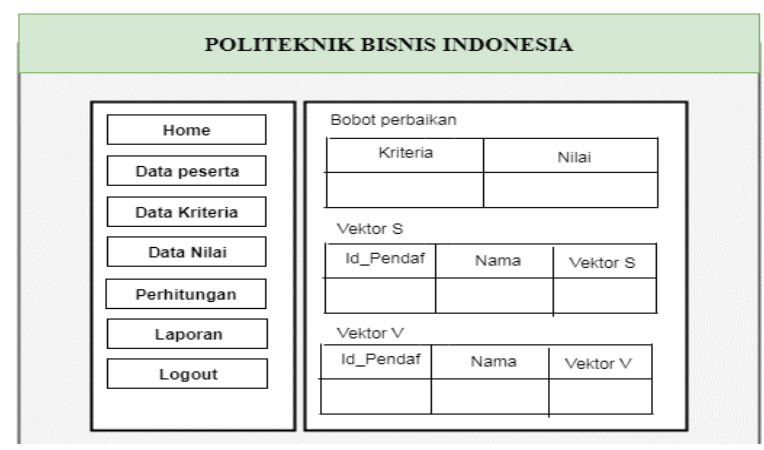

Gambar 10. Halaman perhitungan

\section{Halaman Laporan}

Halaman ini berfungsi untuk menampilkan hasil dari seluruh perhitungan, nilai teratas hingga terendah. Dapat dilihat pada gambar 11 .

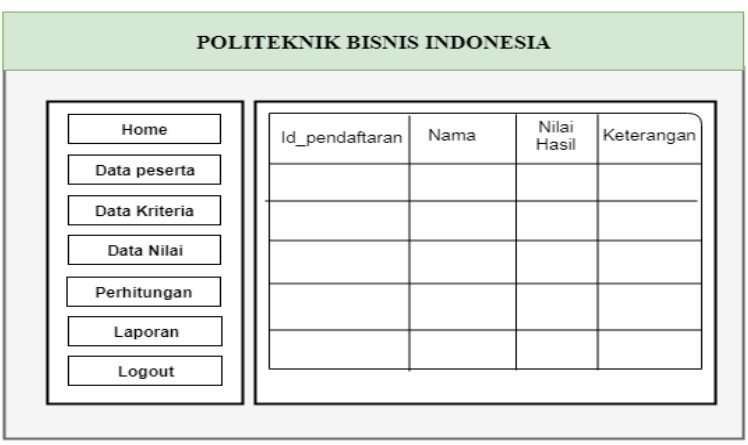

Gambar 11. Halaman Laporan

\section{HASIL DAN PEMBAHASAN}

Setelah memenuhi kebutuhan sistem, proses selanjutnya adalah menjelaskan dan menguji fungsi setiap halaman yang ada di dalam Website untuk Sistem Pendukung Keputusan Penerimaan Mahasiswa Baru menggunakan metode Weighted Product.

\section{Halaman Login}

Untuk dapat mengakses menu utama, admin harus Login dengan memasukan username dan password, kemudian pilih login untuk masuk kedalam sistem. Tampilan Halaman Login dapat dilihat pada gambar 12 .

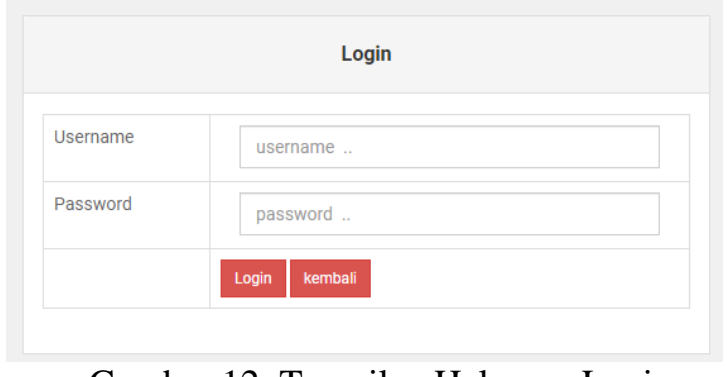

Gambar 12. Tampilan Halaman Login

\section{Halaman Beranda}

Halaman beranda atau halaman utama merupakan tampilan antar muka yang muncul ketika proses autentikasi username dan password pada login telah divalidasi. Pada halaman utama ini terdapat terdapat beberapa menu yang mucul seperti pada gambar 13 .

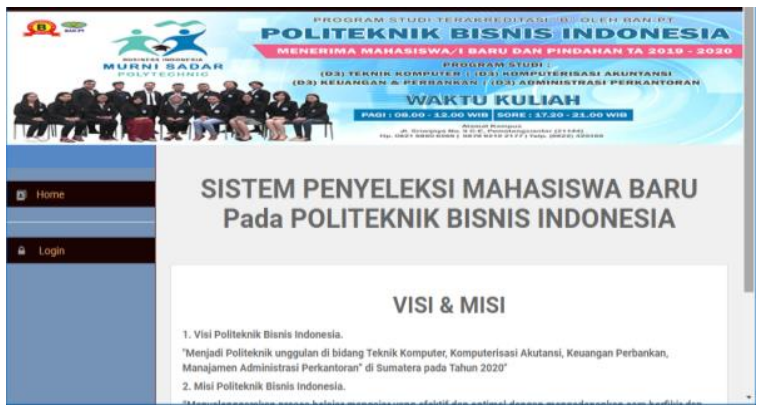

Gambar 13. Tampilan Halaman Beranda

\section{Halaman Calon Mahasiswa}

Ketika admin memilih sub data peserta, dengan mengklik data peserta yang ada pada tampilan menu utama,maka akan muncul data tampilan calon mahasiswa yang telah terisi. 
Tampilan data calon mahasiswa dapat dilihat seperti pada gambar 14 .

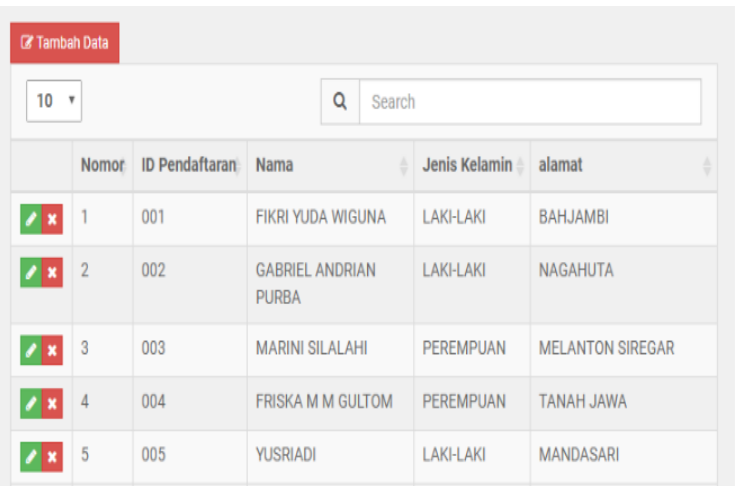

Gambar 14. Halaman Calon Mahasiswa

Pada halaman data peserta terdapat field "Search" dan pilihan yaitu edit, dan delete. Untuk menambahkan data calon mahasiswa baru, admin dapat memilih tombol "Tambah data", maka akan tampil halaman tambah data mahasiswa, setelah mengisikan semua datadata mahasiswa pilih tombol "Simpan" maka secara otomatis data yang di-input-kan akan tersimpan.

\section{Halaman Kriteria Penilaian}

Ketika admin memilih sub data kriteria, maka akan muncul sub kriteria dengan tampilan nama kriteria keterangan serta bobot dari setiap kriteria. Tampilan Halaman kriteria dapat dilihat seperti gambar 15.

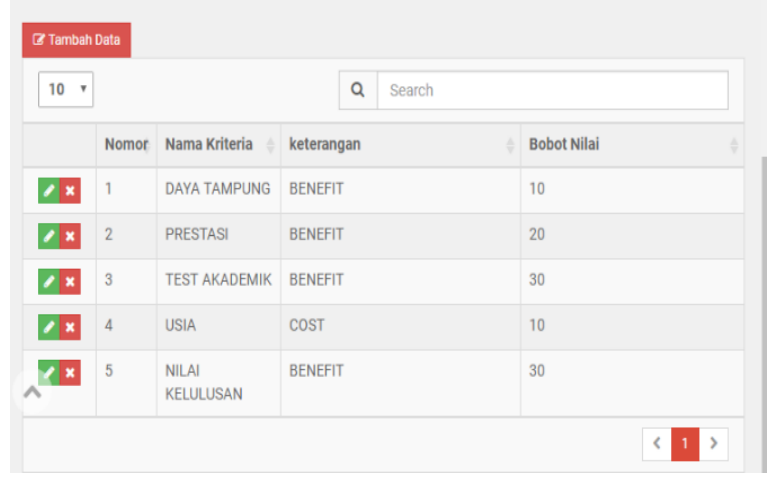

Gambar 15. Halaman Kriteria Penilaian

\section{Halaman Penilaian Alternatif}

Pada saat admin memilih sub menu data nilai maka akan muncul tampilan halaman penilaian alternatif yang menampilkan semua nilai dari data peserta pada setiap kriteria. Tampilan nilai dapat dilihat pada gambar 16 .

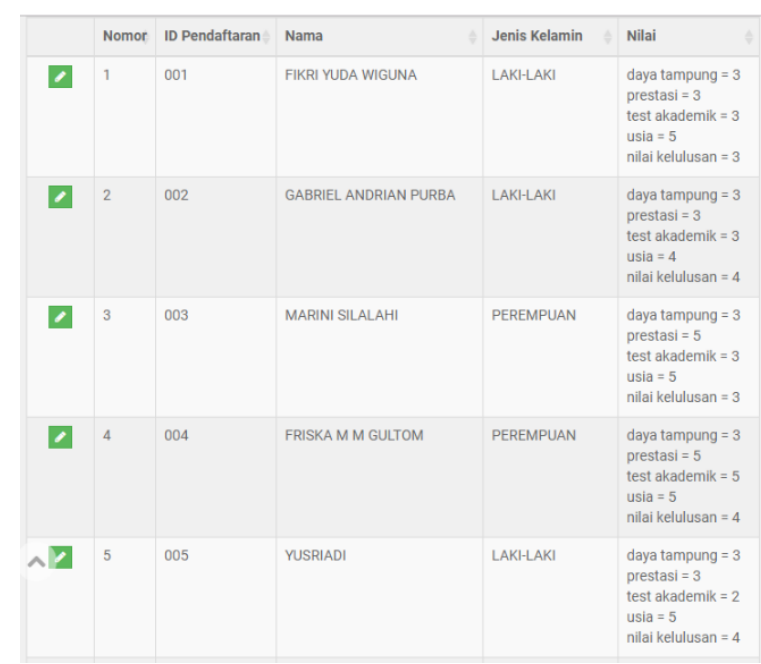

Gambar 16. Halaman Penilaian Alternatif

\section{Halaman Pemasukan Kuota Penerimaan Mahasiswa Baru}

Ketika admin memilih sub laporan, maka akan muncul tampilan halaman Input Kuota Penerimaan Mahasiswa Baru, kemudian admin memasukkan jumlah data mahasiswa yang di terima. Bertujuan untuk membatasi berdasarkan kuota penerimaan calon mahasiswa baru, kemudian klik simpan. Berikut ini proses input kuota calon mahasiswa yang akan diterima. Tampilan input kuota dapat dilihat seperti pada gambar 17.

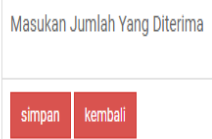

Gambar 17. Halaman Input Kuota Penerimaan Mahasiswa Baru

\section{Halaman Hasil Akhir Analisis Weighted Product}

Setelah di simpan maka otomatis akan muncul laporan yang menunjukkan hasil seleksi berupa jumlah nilai yang diperoleh dan rangking dari masing-masing calon mahasiswa secara urut dimulai dari peringkat teratas atau nilai tertinggi hingga terbawah atau nilai terendah. Hasil penyeleksian dapat dilihat pada gambar 18 . 


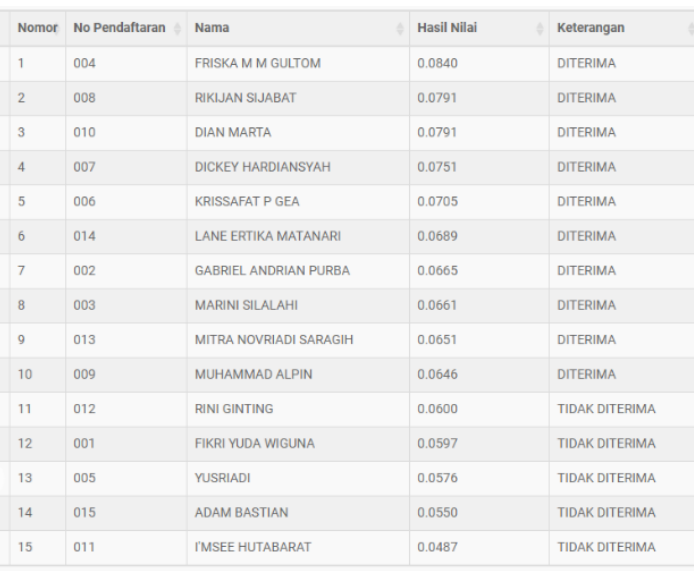

Gambar 18. Hasil Akhir Analisis Weighted Product

\section{Halaman Pencetakan Laporan}

Pada halaman laporan admin atau pengguna dapat mencetak hasil dari perhitungan tersebut sebagai output dari Sistem Pendukung Keputusan yang telah dibuat, dengan memilih tombol "cetak laporan" maka akan tampil halaman cetak secara otomatis. Tampilan halaman cetak dapat dilihat seperti pada gambar 19.

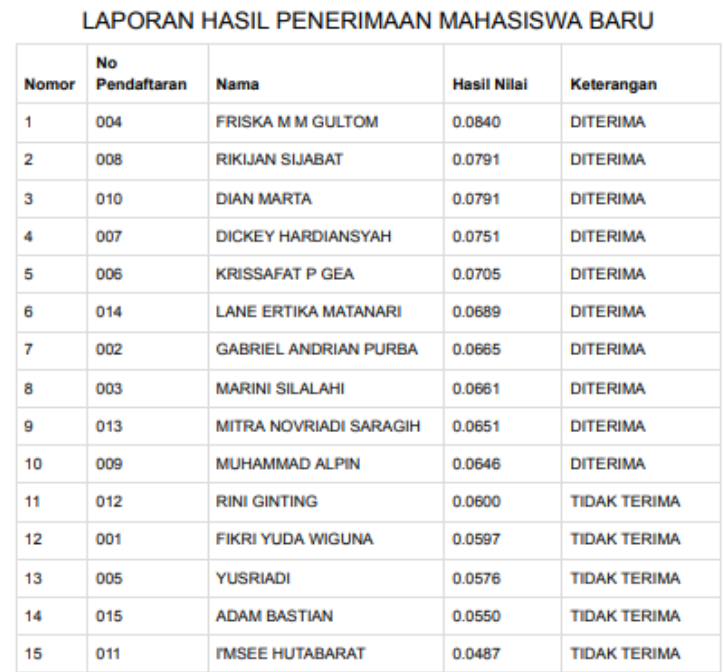

Gambar 19. Tampilan Cetak Laporan

\section{KESIMPULAN}

Berdasarkan Sistem Penyeleksi Mahasiswa Baru yang telah dibangun dapat disimpulkan bahwa Sistem pendukung keputusan yang diterapkan dengan menggunakan metode
Weighted Product ini dapat mempermudah dalam pengambilan keputusan seleksi mahasiswa baru.

\section{REFERENSI}

[1] S. Aisyah and W. Purba, "Aplikasi Sistem Pendukung Keputusan Penilaian Kinerja Karyawan Menggunakan Metode Profile Matching," J. Mahajana Inf., vol. 4, no. 2, pp. 16-20, 2019.

[2] A. T. Purba, "Sistem Pendukung Keputusan Dalam Penerimaan Mahasiswa Baru Dengan Metode Analytical Hierarchy Process (AHP)," J. Tekinkom, vol. 1, no. 1, pp. 1-7, 2018.

[3] Sahat Sonang, "Implementasi K-Means Dalam Evaluasi Kinerja Dosen Politeknik Bisnis Indonesia," J. Tekinkom, vol. 1, no. 1, pp. 32-40, 2018.

[4] J. Simatupang, "Sistem Pendukung Keputusan Penentuan Karyawan Terbaik Menggunakan Metode Saw Studi Kasus Amik Mahaputra Riau," J. Intra-Tech, vol. 2, no. 1, pp. 73-82, 2018.

[5] S. P. Tamba, P. Wulandari, M. Hutabarat, M. Christina, and A. Oktavia, "PENGGUNAAN METODE TOPSIS (TECHNIQUE FOR ORDER PREFERENCE BY SIMILARITY TO IDEAL SOLUTION) UNTUK MENENTUKAN KUALITAS BIJI KOPI TERBAIK BERBASIS ANDROID," $J$. Mantik Penusa, vol. 3, no. 1, pp. 73-81, 2019.

[6] M. A. Salim, "Sistem Pendukung Keputusan Pemilihan Penerima Bantuan Perbaikan Rumah Menggunakan Metode Simple Additive Wieghting (SAW) Studi Kasus Kelurahan Tambelan Sampit Kota Pontianak," J. Sist., vol. 7, no. 2, pp. 120131, 2018.

[7] P. Adi, D. Prasetya, A. Setiawan, N. Nachrowie, and R. Arifuddin, "Design Of Tsunami Detector Based Sort Message Service Using Arduino and SIM900A to GSM/GPRS Module," Proc. Proc. 2nd Int. Conf. Adv. Sci. Innov. ICASI 2019, 18 July, Banda Aceh, Indones., 2019.

[8] P. D. Prasetyo Adi and A. Kitagawa, "Performance evaluation WPAN of RN42 bluetooth based (802.15.1) for sending the multi-sensor LM35 data temperature 
and raspBerry pi 3 Model B for the database and internet gateway," Int. J. Adv. Comput. Sci. Appl., 2018.

[9] P. D. P. Adi and A. Kitagawa, "ZigBee Radio Frequency (RF) performance on Raspberry Pi 3 for Internet of Things (IoT) based blood pressure sensors monitoring," Int. J. Adv. Comput. Sci. Appl., 2019.

[10] P. D. P. Adi and A. Kitagawa, "A Review of the Blockly Programming on M5Stack Board and MQTT Based for Programming Education," 2019 IEEE 11th Int. Conf. Eng. Educ., pp. 102-107, Nov. 2019.

[11] M. Niswar et al., "Performance evaluation of ZigBee-based wireless sensor network for monitoring patients' pulse status," in Proceedings - 2013 International Conference on Information Technology and Electrical Engineering: "Intelligent and Green Technologies for Sustainable Development", ICITEE 2013, 2013.

[12] N. A. Sinaga and S. Sirait, "SISTEM INFORMASI ADMINISTRASI KEPENDUDUKAN ( STUDI KASUS : DESA PARSAORAN AJIBATA KECAMATAN AJIBATA KABUPATEN TOBA SAMOSIR )," TEKINKOM, vol. 2, no. 2, pp. 137-144, 2019.

[13] S. S. S, A. T. Purba, and F. O. I. Pardede, "PENGELOMPOKAN JUMLAH PENDUDUK BERDASARKAN KATEGORI USIA DENGAN METODE K-MEANS," TEKINKOM, vol. 2, no. 2, pp. 166-172, 2019.

[14] V. M. M. Siregar, "Perancangan Sistem Informasi Inventaris Barang Pada Sekolah SMA Negeri 4 Pematangsiantar," IT J. Res. Dev., vol. 3, no. 1, pp. 54-61, 2018.

[15] S. P. Tamba, M. D. Batubara, W. Purba, M. Sihombing, V. M. Mulia Siregar, and J. Banjarnahor, "Book data grouping in libraries using the k-means clustering method," J. Phys. Conf. Ser., vol. 1230, no. 1, p. 012074, Jul. 2019.

[16] H. A. Simbolon and V. M. M. Siregar, "Perancangan Sistem Informasi Berbasis E-Commerce Untuk Peningkatan Penjualan Produk Jersey Olah Raga," J.
Tek. Inf. dan Komput., vol. 1, no. 2, pp. 49-54, 2018.

[17] V. M. M. Siregar, H. Sugara, and G. A. Purba, "Aplikasi Pencatatan Laporan Penjualan Kita-Kita.Net Berbasis Web," TEKINKOM, vol. 2, no. 1, pp. 80-86, 2019.

[18] V. M. Siregar and H. Sugara, "Perancangan Dan Implementasi Aplikasi Penggajian Berbasis Dekstop Pada Murni Sadar English Course," J. Tek. Inf. dan Komput., vol. 1, no. 2, pp. 42-48, 2018.

[19] R. Fitria and S. N. Rakhmah, "Penerapan Metode Weighteded Product Untuk Menganalisis Faktor Pemilihan Pembayaran Digital Transaction Pada Aplikasi Ojek Online," J. Tek., vol. 11, no. 2, pp. 1098-1103, 2019.

[20] N. Pakaya, "Pemuda Nusantara Dengan Menggunakan Metode," ILKOM, vol. 9, no. 3, pp. 331-337, 2017.

[21] S. Amelia, "Rancang Bangun Sistem Penilaian Artikel Menggunakan Metode Weighteded Product (Wp) Pt Pos Indonesia (Persero)," J. Ilm. Inform., vol. 7, no. 02, pp. 67-75, 2019.

[22] Z. Alamsyah and D. Gustian, "Sistem Pendukung Keputusan Menggunakan Metode Weighteded Product Dan Simple Additive Terhadap Penerimaan Guru," $J$. IKRA-ITH Inform., vol. 3, no. 1, pp. 129137, 2019.

[23] R. Roni, S. Sumijan, and J. Santony, "Metode Weighteded Product dalam Pemilihan Penerima Beasiswa Bagi Peserta Didik," J. RESTI (Rekayasa Sist. dan Teknol. Informasi), vol. 3, no. 1, pp. 87-93, 2019.

[24] Y. Perwira, "Penentuan Peringkat Pelanggan Terbaik Dengan Metode Weighteded Product (Studi Kasus PT. Asia Raya Foundry)," J. Mantik Penusa, vol. 3, no. 1, pp. 138-147, 2019. 